\title{
Relationship among phenotypic and quality traits in indigenous and exotic accessions of linseed
}

\author{
Ameena Siddiqui(1), Sudhir Shukla(1), Anu Rastogi(1), Atul Bhargava( ${ }^{(2)}$, Abhishek Niranjan $^{(3)}$ and Alok Lehri( ${ }^{(3)}$
}

(1)CSIR-National Botanical Research Institute, Department of Genetics and Plant Breeding, Lucknow 226001, Uttar Pradesh, India. E-mail: siddiqui.ameena@gmail.com, sudhirshukla@nbri.res.in, anu_subhi2001@yahoo.com (2)Amity Institute of Biotechnology, Amity University Uttar Pradesh, Lucknow Campus, Lucknow-226028, India. E-mail: abhargava@amity.edu ${ }^{(3)}$ CSIR-National Botanical Research Institute, Central Instrumentation Facility, Lucknow 226001, Uttar Pradesh, India. E-mail: abhishek-niranjan@yahoo.co.in, a.lehri@nbri.res.in

\begin{abstract}
The objective of this work was to evaluate the relationship among phenotypic and quality traits in a set of indigenous and exotic accessions of linseed (Linum usitatissimum). The experimental material consisted of 151 accessions of linseed belonging to landraces and cultivars collected from diverse agroecological zones. Five randomly chosen plants of each accession in each replicate were tagged, and data were recorded for the 12 following agronomic traits: days to flowering, days to maturity, plant weight, plant height, tillers per plant, secondary branches per plant, capsules per plant, seeds per capsule, 1,000 seed weight, harvest index, seed yield per plant, and oil content. Capsules per plant, harvest index, and plant weight played a direct and indirect major role on seed yield. High heritability, coupled with high genetic advance for plant weight, secondary branches per plant, capsules per plant, and seed yield per plant, suggests that selection based on these traits can be effective. Regarding per se performance, the following accessions can be exploited for commercial cultivation: Shweta (5.41 g), Gaurav (5.07 g), and EX-3-3 (4.77 g) for seed yield; and Shubhra (45.09\%), Mukta (44.94\%), Laxmi-27 (45.06\%), and Shweta (44.25\%) for oil content. The chemical profiling of fatty acids obtained in the present study can provide a platform for the selection of accessions for the genetic improvement of linseed.
\end{abstract}

Index terms: Linum usitatissimum, correlation, fatty acids, genetic advance, heritability, path analysis.

\section{Relações entre características fenotípicas e de qualidade em acessos de linhaça nativos e exóticos}

Resumo - O objetivo deste trabalho foi avaliar a relação entre as características fenotípicas e de qualidade de um conjunto de acessos nativos e exóticos de linhaça (Linum usitatissimum). O material avaliado consistiu de 151 acessos de linhaça nativos ou de cultivares obtidas de diferentes zonas agroecológicas. Cinco plantas de cada acesso, selecionadas aletoriamente, foram identificadas, e foram registrados dados para as 12 seguintes características agronômicas: número de dias para o início do florescimento, número de dias para a maturação, peso da planta, altura da planta, número de perfilhos por planta, número de ramos secundários por planta, número de cápsulas por planta, número de sementes por cápsula, peso de mil grãos, índice de colheita, produção de sementes por planta e conteúdo de óleo. O número de cápsulas por planta, o índice de colheita e o peso da planta desempenharam papel importante tanto direta quanto indiretamente na produção de sementes. Altos valores de herdabilidade, associados a alto avanço genético para peso da planta, número de ramos secundários por planta, número de cápsulas por planta e produção de sementes por planta, sugerem que a seleção com base nestas características pode ser eficaz. Em relação ao desempenho per se, os seguintes acessos podem ser explorados em cultivo comercial: Shweta (5,41 g), Gaurav (5,07 g) e EX-3-3 (4,77 g) para produção de sementes; e Shubhra (45,09\%), Mukta (44,94\%), Laxmi-27 (45,06\%) e Shweta (44,25\%) para teor de óleo. O perfil químico dos ácidos graxos obtido no presente trabalho pode fornecer uma plataforma para a seleção de acessos para o melhoramento genético de sementes de linhaça.

Termos para indexação: Linum usitatissimum, correlação, ácidos graxos, avanços genéticos, herdabilidade, análise de trilha.

\section{Introduction}

Linseed (Linum usitatissimum L.), commonly known as "fiber flax" or "oil flax", is being grown primarily as a fiber and oilseed crop. Linseed oil is mainly used by paint and varnish industries due to its fast drying capabilities in comparison with other traditional oils (Bayrak et al., 2010). The species has also been recognized as an excellent source of micronutrients, 
dietary fiber, protein, vitamin B1, lignan, and essential fatty acids (EFA), namely linoleic and alpha-linolenic acids. Its high EFA content also makes its use easier for medicinal purposes and as a food supplement (Elbeltagi, 2007; Abou El-Nasr et al., 2014). In addition, linseed oil is the richest plant source of linoleic (omega-6) and linolenic (omega-3) polyunsaturated fatty acids (Bloedon \& Szapary, 2004).

Considering the great industrial and nutritional importance of the crop, several efforts have been made in India by breeders to increase its productivity, but the national average yield of linseed has been quite low, of $0.4 \mathrm{Mg} \mathrm{ha}^{-1}$ (Yadava et al., 2012). This is primarily attributed to various socioeconomic factors and to the lower accessibility to high-yielding varieties. Moreover, because of its low productivity, the area under linseed cultivation is gradually declining (Chauhan et al., 2009). In this context, the main goal of linseed breeders is the development of cultivars with high grain yield and quality components (Abou El-Nasr et al., 2014). It should be noted that the success of any breeding program relies on a clear understanding of the genetic mechanisms involved in the inheritance of traits, of the correlation between traits, as well as of their heritability, amount of existent variability, and genetic advance (Bhargava et al., 2007; Ahmad et al., 2014; Mili et al., 2014). It is, therefore, imperative to compute the variability present in the available germplasm and to partition it into genotypic, phenotypic, and environmental variations (Bhargava et al., 2007). This information is essential for the selection of traits that affect seed yield either directly or indirectly (Kadri Bozokalfa et al., 2010).

Although literature on the improvement of yield potential is available for linseed, few works have been carried out on improving oil quality, taking into consideration major fatty acids (Bayrak et al., 2010; Pali \& Mehta, 2014). This shows the importance of characterizing the linseed germplasm for different morphological traits and for the elucidation of the fatty acid profile. The obtained information would be useful in formulating comprehensive breeding strategies to improve linseed quantitatively and qualitatively.

The objective of this work was to evaluate the relationship among phenotypic and quality traits in a set of indigenous and exotic accessions of linseed (Linum usitatissimum).

\section{Materials and Methods}

The study was conducted at the experimental field of CSIR-National Botanical Research Institute, in Lucknow, India $\left(26.5^{\circ} \mathrm{N}, 80.5^{\circ} \mathrm{E}\right.$, at an altitude of $120 \mathrm{~m}$ above sea level). The climate of the experimental station is semiarid to subtropical, and linseed is cultivated as a winter crop. During the growth period, day temperature ranged from 15 to $20^{\circ} \mathrm{C}$ and night temperature from 2 to $12^{\circ} \mathrm{C}$, while, during the harvest period, day temperature was $35-42^{\circ} \mathrm{C}$ and night temperature was $22-30^{\circ} \mathrm{C}$. The soil of the experimental site is an Inceptisol Ustept, Fluventic Haplustept, with fine loam texture (Singh et al., 2004), $6.8 \pm 0.04 \mathrm{pH}$, $479 \pm 1.26 \mu \mathrm{s} \mathrm{cm}^{-1}$ electrical conductivity, and $1.06 \%$ organic matter content.

The experimental material consisted of 151 accessions of linseed belonging to landraces and cultivars collected from diverse agroecological zones; the different varieties and hybrids were developed in several research organizations and were obtained from Chandra Shekhar Azad University of Agriculture \& Technology, located in Kanpur, India, and from Acharya Narendra Dev University of Agriculture \& Technology, located in Faizabad, also in India. The exotic accessions are being maintained in the seed bank of National Bureau of Plant Genetic Resources, in New Delhi, India (Table 1).

The seeds were sown in a randomized complete block design with three replicates, in the first week of November, for two consecutive years (2012-2013 and 2013-2014), as a winter crop. The row-to-row and plant-to-plant distance was kept at 40 and $15 \mathrm{~cm}$, respectively. In a replicate, each accession was grown in three $3 \mathrm{~m}$ long rows. For the whole crop season, weeding followed by hoeing was done at an interval of 15 days. Irrigation was provided when needed, and urea was applied at $40 \mathrm{~kg} \mathrm{ha}^{-1}$ in three splits.

Five randomly chosen plants of each accession in each replicate were tagged, and data were recorded for 12 agronomic traits, namely: days to flowering, days to maturity, plant weight $(\mathrm{g})$, plant height $(\mathrm{cm})$, tillers per plant, secondary branches per plant, capsules per plant, seeds per capsule, 1,000 seed weight (g), harvest index (\%), seed yield per plant (g), and oil content $(\%)$. The harvest index was calculated in percentage as the ratio of seed yield to plant weight after plant maturity.

Five major fatty acids - palmitic, stearic, oleic, linoleic, and linolenic acids - were estimated through

Pesq. agropec. bras., Brasília, v.51, n.12, p.1964-1972, dez. 2016 DOI: 10.1590/S0100-204X2016001200007 
gas liquid chromatography. One microliter of prepared methyl esters from the sample was injected in the injector of the Hewlett Packard 6890 chromatograph with a DB-225 Durabond capillary column, with $30 \mathrm{~m}$ length and $0.32 \mathrm{~mm}$ diameter (Agilent Technologies, Santa Clara, CA, USA); the temperature program was $90^{\circ} \mathrm{C}$ for $5 \mathrm{~min}$ to $130^{\circ} \mathrm{C}$ at $3^{\circ} \mathrm{C}$ per minute, and $130^{\circ} \mathrm{C}$ for $12 \mathrm{~min}$ to $230^{\circ} \mathrm{C}$ at $2^{\circ} \mathrm{C}$ per minute. The temperature of the injection port was maintained at $230^{\circ} \mathrm{C}$, at the split ratio of $50: 1$, and the temperature of the flame ionization detector was kept at $240^{\circ} \mathrm{C}$. Nitrogen at $2 \mathrm{~mL}$ per minute was used as the carrier gas. Methyl esters of fatty acids for analysis were prepared by the standard protocol adopted in India.

Table 1. Names, types, origin, sources, and geographic coordinates of the 151 accessions of linseed (Linum usitatissimum) evaluated in 2012-2013 and 2013-2014.

\begin{tabular}{|c|c|c|c|c|}
\hline Accessions & Types & Origin $^{(1)}$ & Source $^{(2)}$ & $\begin{array}{l}\text { Geographical } \\
\text { coordinates }\end{array}$ \\
\hline $\begin{array}{l}\text { EC-41750, EC-41752, EC-41984, EC-50089, EC-51904, EC- } \\
\text { 59202, EC-98866, EC-98987, EC-98989, EC-98990, EC-98991, } \\
\text { EC-98992, EC-98994, EC-98995, EC-98996, EC-98998, EC- } \\
\text { 99001, EC-99005, EC-99006, EC-99007, EC-99008, EC-99009, } \\
\text { EC-99012, EC-99017, EC-99020, EC-99022, EC-99023, EC- } \\
\text { 99024, EC-99025, EC-99029, EC-99039, EC-99056, EC-104736, } \\
\text { EC-104738, EC-104739, EC-109440 (Crista), EC-110286, } \\
\text { EC-110288, EC-110289, EC-112689, EC-115161, EC-115162, } \\
\text { EC-115169, EC-115178, EC-115179, EC-115181, EC-115182, EC- } \\
\text { 115186, EC-225125, EC-411539, EC-1041492, and Flax C-16 }\end{array}$ & Exotic & $\begin{array}{c}\text { USA; Russia; } \\
\text { Canada; and Argentina }\end{array}$ & $\begin{array}{l}\text { NBPGR, located in } \\
\text { New Delhi, India }\end{array}$ & $\begin{array}{c}28.61^{\circ} \mathrm{N} \\
77.20^{\circ} \mathrm{E} \\
229 \mathrm{~m}^{\text {above } \mathrm{msl}^{(3)}}\end{array}$ \\
\hline Eita & Exotic & Germany & $\begin{array}{l}\text { CSAUAT, located in } \\
\text { Kanpur, India }\end{array}$ & $\begin{array}{c}26.44^{\circ} \mathrm{N} \\
80.33^{\circ} \mathrm{E} \\
131 \mathrm{~m} \text { above } \mathrm{msl} \\
\end{array}$ \\
\hline $\begin{array}{l}\text { T-397, Hira, Mukta, AKL-89, AKG-812A, Gaurav, Surabhi, } \\
\text { Shweta, Laxmi-27, Neelam, Shubhra, and Garima }\end{array}$ & Indigenous & Kanpur, India & $\begin{array}{l}\text { CSAUAT, located in } \\
\text { Kanpur, India }\end{array}$ & $\begin{array}{c}26.44^{\circ} \mathrm{N} \\
80.33^{\circ} \mathrm{E} \\
131 \mathrm{~m} \text { above } \mathrm{msl} \\
\end{array}$ \\
\hline $\begin{array}{l}\text { A-705, A-95, A-131, A-69, A-993, A-496, A-159, A-155, A-53, } \\
\text { A-148, A-179, A-121, A-114, A-113, A-166, A-165, A-164, A-161, } \\
\text { A-112, A-78, A-84, A-83, A-81, A-80, A-79, A-66, A-76, A-73, } \\
\text { A-72, A-71, A-70,A-94, A-103, A-77, and A-03 }\end{array}$ & Indigenous & $\begin{array}{l}\text { IARI, located in Pusa, } \\
\text { India }\end{array}$ & $\begin{array}{l}\text { NDUAT, located in } \\
\text { Faizabad, India }\end{array}$ & $\begin{array}{c}26.77^{\circ} \mathrm{N} \\
82.14^{\circ} \mathrm{E} \\
97 \mathrm{~m} \text { above } \mathrm{msl}\end{array}$ \\
\hline Ajgan-11, Ajgan-13, and Ajgan-14 & Indigenous & $\begin{array}{l}\text { Ajgan, Uttar Pradesh, } \\
\text { India }\end{array}$ & $\begin{array}{l}\text { NDUAT, located in } \\
\text { Faizabad, India }\end{array}$ & $\begin{array}{c}26.77^{\circ} \mathrm{N} \\
82.14^{\circ} \mathrm{E} \\
97 \mathrm{~m} \text { above } \mathrm{msl} \\
\end{array}$ \\
\hline $\begin{array}{l}\text { EI-47-21-42, EI-5611, EI-5613, ES-567, ES-1440, ES-1444, } \\
\text { ES-1445, ES-1449, ES-1456, ES-1474, ES-1534, ES-15980, ES- } \\
\text { 16381, EX-3, EX-3-3, EX-5-36-E, EX-6-3, EX-28-3, EX-53-913, } \\
\text { EX-79-59, EX-304-1, FR-3, FR-11, FR-15, FRW-6, FRW-9, FRW- } \\
\text { 12, AB-O, and RS-25 }\end{array}$ & --------- & --------------- & $\begin{array}{l}\text { CSAUAT, located in } \\
\text { Kanpur, India }\end{array}$ & $\begin{array}{c}26.44^{\circ} \mathrm{N} \\
80.33^{\circ} \mathrm{E} \\
131 \mathrm{~m} \text { above } \mathrm{msl}\end{array}$ \\
\hline NDL-97-6 and NDL-97-5 & Indigenous & $\begin{array}{l}\text { Faizabad, Uttar Pradesh, } \\
\text { India }\end{array}$ & $\begin{array}{l}\text { NDUAT, located in } \\
\text { Faizabad, India }\end{array}$ & $\begin{array}{c}26.77^{\circ} \mathrm{N} \\
82.14^{\circ} \mathrm{E} \\
97 \mathrm{~m} \text { above } \mathrm{msl} \\
\end{array}$ \\
\hline $\begin{array}{l}\text { BAU-141, BAU-154, BAU-147, BAU-111-1, BAU-189-2, and } \\
\text { BAU-45 }\end{array}$ & Indigenous & $\begin{array}{l}\text { Birsa Agricultural } \\
\text { University, located in } \\
\text { Ranchi, Jharkhand, } \\
\text { India } \\
\end{array}$ & $\begin{array}{l}\text { NDUAT, located in } \\
\text { Faizabad, India }\end{array}$ & $\begin{array}{c}26.77^{\circ} \mathrm{N} \\
82.14^{\circ} \mathrm{E} \\
97 \mathrm{~m} \text { above } \mathrm{msl}\end{array}$ \\
\hline $\begin{array}{l}\text { BR-8, BR-17, BR-5, BS-2, BR-2, BS-26, BS-28, BR-29, and BR- } \\
70\end{array}$ & Indigenous & Sabour, Bihar, India & $\begin{array}{l}\text { NDUAT, located in } \\
\text { Faizabad, India }\end{array}$ & $\begin{array}{c}26.77^{\circ} \mathrm{N} \\
82.14^{\circ} \mathrm{E} \\
97 \mathrm{~m} \text { above } \mathrm{msl} \\
\end{array}$ \\
\hline Aayogi & Indigenous & ----------- & $\begin{array}{l}\text { NDUAT, located in } \\
\text { Faizabad, India }\end{array}$ & $\begin{array}{c}26.77^{\circ} \mathrm{N} \\
82.14^{\circ} \mathrm{E} \\
97 \mathrm{~m} \text { above } \mathrm{msl} \\
\end{array}$ \\
\hline R-558 & Indigenous & $\begin{array}{l}\text { Raipur, Chhattisgarh, } \\
\text { India }\end{array}$ & $\begin{array}{l}\text { CSAUAT, located in } \\
\text { Kanpur, India }\end{array}$ & $\begin{array}{c}26.44^{\circ} \mathrm{N} \\
80.33^{\circ} \mathrm{E} \\
131 \mathrm{~m} \text { above } \mathrm{msl}\end{array}$ \\
\hline
\end{tabular}

(1)IARI, Indian Agricultural Research Institute. ${ }^{(2)}$ NBPGR, National Bureau of Plant Genetic Resources; CSAUAT, Chandra Shekhar Azad University of Agriculture \& Technology; and NDUAT, Narendra Dev University of Agriculture \& Technology. ${ }^{(3)}$ Mean sea level. 
The oil was extracted from $20 \mathrm{~g}$ crushed seeds of each accession through the Soxhlet method. Two $\mathrm{mL}$ oil of each accession were refluxed in a condenser with $20 \mathrm{~mL}$ of methanolic sodium hydroxide for 1-2 hours until the color of the oil turned from yellow to orange. After reflux, $5 \mathrm{~mL}$ of water containing $1 \mathrm{~mL}$ of hydrochloric acid were added and extracted with 10 $\mathrm{mL}$ of petroleum ether, and the process was repeated two times, followed by washing with water using a separating funnel. Then, the extract was passed through anhydrous sodium sulfate to absorb moisture content, and petroleum ether was evaporated using a rotary vacuum evaporator. Afterwards, $10 \mathrm{~mL}$ of methanol and 1-2 drops of concentrated $\mathrm{H}_{2} \mathrm{SO}_{4}$ were added to obtain free fatty acids, which were further subjected to reflux for 2 hours. The extraction and washing steps were repeated, followed by filtration through sodium sulfate. After the evaporation of petroleum ether, fatty acid methyl esters were obtained and were analyzed through gas liquid chromatography. The standards of fatty acids, as methyl esters, were obtained from Sigma-Aldrich (St. Louis, MO, USA). The percentage of fatty acids was analyzed based on peak area.

The mean data of the three replicates over the two evaluated years were subjected to statistical analyses using the Windostat software, version 8.5 (Indostat Services, Hyderabad, India). The analysis of variance was done according to Panse \& Sukhatme (1967). Furthermore, the significance of the mean values of the accessions was tested against the overall mean of the particular trait based on the critical difference at $5 \%$. Several parameters of genetic variability, including phenotypic coefficient of variation (PCV), genotypic coefficient of variation (GCV), broad-sense heritability, and genetic advance, were evaluated according to Singh \& Chaudhary (1985), using the expression: genetic advance $=\sigma \mathrm{PH}$, in which $\sigma$ is the selection differential at 5\% selection intensity (2.06), $\mathrm{P}$ is the phenotypic standard deviation, and $\mathrm{H}$ is the heritability coefficient. Correlation and path analyses were carried out by the method suggested by Johnson et al. (1955b) and Dewey \& Lu (1959), respectively.

\section{Results and Discussion}

The analysis of variance for the two experimental years revealed differences among the accessions for all traits, which validated further statistical and genetic analyses. These results showed the presence of a high degree of morphological and qualitative variation among the studied accessions. The large variation in linseed accessions regarding the different quantitative and qualitative traits was mainly due to the fact that the species grows in diverse agroclimatic conditions in the country, indicating that their populations might have experienced marked differences in selection pressure.

The range of variation between the highest and lowest mean values of the accessions for each trait was significantly high (Table 2). On the basis of per se performance, no single accession performed better for all traits. The Shubhra, Shweta, and EX-3-3 accessions showed high oil content and, when coupled with high linoleic and linolenic acid, could be used as donor parents for quality improvement. The Shweta $(5.41 \mathrm{~g})$, Gaurav (5.07 g), and EX-3-3 (4.77 g) accessions showed higher seed yield, whereas Shubhra (45.09\%) and Laxmi-27 (45.06\%), followed by Mukta (44.94\%) and Shweta (44.25\%), had significantly high oil content. Therefore, recurrent selection among the population of these accessions can further increase seed yield as well as oil content. This shows that accessions with high content of different fatty acids can also be further exploited through recurrent selection.

Variability plays an important role in any crop breeding program and determines the limit of selection for yield improvement (Bhargava et al., 2007; Mohammadi, 2010; Usmani et al., 2014). In addition, a wide range of variability specifies a better scope of selection. In the present study, GCV and PCV values were of $3.17-34.93 \%$ and $3.45-35.72 \%$, respectively (Table 2). The wide variation in genotypic values resulting in genotypic variances $\left(\sigma^{2} \mathrm{~g}\right)$ for all traits was greater than the residual $\sigma^{2}$ e values. PCV had a higher estimate than GCV for all traits, although the differences were minor, which showed that these traits were slightly affected by the environment and were mainly governed by genetic factors (Vardhan \& Rao, 2012). The high GCV and PCV exhibited by plant weight, seed yield, and secondary branches indicated that there is a good scope for improvement in these traits through selection in the segregating population. High estimates of GCV and PCV for seed yield in linseed have also been previously reported by Tadesse et al. (2010) and Mirza et al. (2011). The occurrence of moderate estimates of GCV and PCV, high heritability, and moderate to high genetic advance for the rest of the traits, including plant height, tillers per capsules,

Pesq. agropec. bras., Brasília, v.51, n.12, p.1964-1972, dez. 2016 DOI: 10.1590/S0100-204X2016001200007 
capsules per plant, test weight, seed yield per plant, harvest index, oil content, and fatty acids, implies that improvement in these traits can be achieved up to a reasonable extent through selection.

Heritability estimates were generally high for all traits, ranging from 0.72-0.99 (Table 2). These high estimates indicated that all traits were less affected by the environment and that they can be improved through selection. Similar findings have also been reported by Tadesse et al. (2010), Mirza et al. (2011), Bibi et al. (2013), and Ahmad et al. (2014). However, the estimation of heritability is of little significance in coherent selection breeding programs, unless accompanied by sufficient genetic advance (Johnson et al., 1955a).

In a selection program, the primary objective is trait improvement, indicating that a study on genetic advance proves more beneficial, in addition to heritability (Johnson et al., 1955a). Genetic advance ranged from $6.00-70.36 \%$ among all traits. However, high heritability, coupled with a high genetic advance, was observed for plant weight, secondary branches per plant, capsules per plant, and seed yield per plant, which implies that heritability is most likely due to additive gene effects and that selection is probably effective (Ahmad et al., 2014). Panse (1957) suggested that a character governed by high heritability and high genetic advance may possibly be due to additive gene action. However, traits such as days to flowering, days to maturity, and seeds per capsule showed high heritability with low genetic advance. This shows that nonadditive gene action and selection for these traits may not be rewarding. Bibi et al. (2013) also reported high heritability with low genetic advance for days to flowering and days to maturity in linseed. In the present study, high heritability with moderate genetic advance was observed for all fatty acids. Likewise, Pali \& Mehta (2014) found high heritability with moderate genetic advance for oil content and all fatty acid components in 48 varieties of linseed, suggesting that selection per se would be rewarding for these traits.

To achieve rational improvement in yield and in its components, knowledge of genetic association, as well as of the cause and effectrelationship, provides a strong basis for formulating a suitable selection method. Correlation coefficients show relationships among several traits and the degree of the linear relationship between them. In the present study, genotypic correlation coefficients between different character pairs were generally similar to the corresponding phenotypic correlation coefficient (Table 3). However, genotypic correlations were higher in magnitude than the corresponding phenotypic correlation for all traits, revealing that environment had a small role in the expression of the traits, which

Table 2. Genetic parameters estimated over the means of data collected during two years for 17 different morphological, agronomical, and chemical traits of 151 accessions of linseed (Linum usitatissimum) evaluated in 2012-2013 and 2013$2014^{(1)}$.

\begin{tabular}{|c|c|c|c|c|c|c|c|c|c|c|}
\hline Traits & Mean \pm SE & Range & GCV $(\%)$ & PCV $(\%)$ & $\sigma^{2} \mathrm{~g}$ & $\sigma^{2} \mathrm{p}$ & $\sigma^{2} \mathrm{e}$ & $h^{2}(\%)$ & GA & GA (\%) \\
\hline Days to flowering & $75.45 \pm 1.07$ & $49.16-87.66$ & 8.38 & 8.56 & 39.99 & 41.73 & 1.74 & 95.82 & 12.75 & 16.90 \\
\hline Days to maturity & $133.87 \pm 1.49$ & $122.83-141.83$ & 3.17 & 3.45 & 18.01 & 21.34 & 3.33 & 84.40 & 8.03 & 6.00 \\
\hline Plant weight (g) & $12.00 \pm 0.72$ & 5.31-23.19 & 30.13 & 31.02 & 13.08 & 13.86 & 0.78 & 94.34 & 7.23 & 60.29 \\
\hline Plant height $(\mathrm{cm})$ & $72.78 \pm 2.30$ & $51.22-109.27$ & 13.49 & 14.03 & 96.42 & 104.43 & 8.00 & 92.34 & 19.43 & 26.70 \\
\hline Tillers per plant & $4.94 \pm 0.50$ & $2.50-9.22$ & 24.84 & 27.83 & 1.50 & 1.89 & 0.38 & 79.70 & 2.25 & 45.69 \\
\hline Capsules per plant & $76.39 \pm 3.52$ & $36.64-117.28$ & 25.61 & 26.22 & 382.92 & 401.54 & 18.62 & 95.36 & 39.36 & 51.52 \\
\hline Seeds per capsule & $8.10 \pm 0.34$ & $5.50-9.95$ & 9.35 & 10.74 & 0.57 & 0.75 & 0.18 & 75.88 & 1.35 & 16.78 \\
\hline Test weight (g) & $5.94 \pm 0.28$ & $4.25-7.88$ & 13.92 & 15.09 & 0.68 & 0.80 & 0.11 & 85.15 & 1.57 & 26.47 \\
\hline Seed yield $(g)$ & $2.79 \pm 0.17$ & $0.98-5.41$ & 34.93 & 35.72 & 0.95 & 0.99 & 0.04 & 95.60 & 1.96 & 70.36 \\
\hline Harvest index (\%) & $23.27 \pm 1.52$ & $15.16-34.70$ & 12.90 & 15.20 & 9.01 & 12.52 & 3.50 & 72.00 & 5.24 & 22.55 \\
\hline Oil content $(\%)$ & $35.67 \pm 0.74$ & $23.20-45.09$ & 13.45 & 13.70 & 23.06 & 23.90 & 0.84 & 96.48 & 9.71 & 27.23 \\
\hline SB & $17.72 \pm 1.73$ & $6.28-42.47$ & 32.01 & 34.18 & 32.21 & 36.72 & 4.51 & 87.71 & 10.94 & 61.77 \\
\hline Palmitic acid (\%) & $5.92 \pm 0.17$ & $2.42-9.40$ & 15.16 & 15.59 & 0.80 & 0.85 & 0.04 & 94.59 & 1.79 & 30.37 \\
\hline Stearic acid (\%) & $4.30 \pm 0.18$ & $2.24-7.41$ & 22.12 & 22.75 & 0.90 & 0.96 & 0.05 & 94.56 & 1.90 & 44.31 \\
\hline Oleic acid (\%) & $24.36 \pm 0.22$ & $11.33-37.38$ & 21.85 & 21.88 & 28.37 & 28.44 & 0.07 & 99.74 & 10.95 & 44.96 \\
\hline Linoleic acid (\%) & $12.64 \pm 0.45$ & $7.25-19.79$ & 20.31 & 20.79 & 6.59 & 6.91 & 0.31 & 95.42 & 5.16 & 40.87 \\
\hline Linolenic acid (\%) & $47.13 \pm 0.23$ & $28.29-59.45$ & 14.41 & 14.42 & 46.18 & 46.26 & 0.083 & 99.82 & 13.98 & 29.67 \\
\hline
\end{tabular}

${ }^{(1)} \mathrm{SB}$, secondary branches per plant; GCV, genotypic coefficient of variation; PCV, phenotypic coefficient of variation; $\sigma^{2} \mathrm{~g}$, genotypic variance; $\sigma^{2} \mathrm{p}$, phenotypic variance; $\sigma^{2}$, error variance; $h^{2}$, broad-sense heritability; and GA, genetic advance. 
suggests an inherent association between these traits at the genetic level (Vardhan \& Rao, 2012; Reddy et al., 2013). Moreover, in the present study, seed yield showed a positive significant genotypic and phenotypic association with days to maturity, days to flowering, plant weight, tillers per plant, secondary branches per plant, capsules per plant, harvest index, and linolenic acid, indicating that selection based on these parameters would considerably enhance seed yield. Besides seed yield, the harvest index showed a significant positive genotypic correlation with days to maturity, plant weight, and capsules per plant, implying that selection based on these three characters could enhance the harvest index, which ultimately would lead to an increase in seed yield. Days to maturity had a significant negative correlation with oil content, suggesting that early maturity would favorably enhance oil content, since it allows access to nutrients for seed filling, which translates into superior seed yield (Tadesse et al., 2010). The highly significant positive correlation of oil content with test weight suggests that heavyweight seeds would also have high oil content. It should be highlighted that the accessions with high per se performance for oil content also have high test weight. Therefore, selection based on test weight could be a reliable approach for the development of varieties rich in oil content. According to Diederichsen \& Fu (2008), the increase in seed weight affects oil concentration and amount per seed. The strong positive correlation observed between oil content and test weight is also in alignment with the findings of

Table 3. Genotypic and phenotypic (between parentheses) correlations estimated over the means of data collected during two years for 17 morphological, agronomical, and chemical traits of 151 accessions of linseed (Linum usitatissimum) evaluated in 2012-2013 and 2013-2014.

\begin{tabular}{|c|c|c|c|c|c|c|c|c|c|c|c|c|c|c|c|c|}
\hline Traits $^{(1}$ & $\mathrm{DM}$ & PW & $\mathrm{PH}$ & $\mathrm{TL}$ & SB & $\mathrm{CP}$ & $\mathrm{SC}$ & $\mathrm{TW}$ & SY & HI & $\mathrm{OP}$ & PA & SA & $\mathrm{OA}$ & LA & LNA \\
\hline$\overline{\mathrm{DF}}$ & $\begin{array}{c}0.443 * * \\
(0.415)^{* *}\end{array}$ & $\begin{array}{c}0.193 \\
(0.186)\end{array}$ & $\begin{array}{c}0.078 \\
(0.076)\end{array}$ & $\begin{array}{c}0.175 \\
(0.142)\end{array}$ & $\begin{array}{c}0.175 \\
(0.152)\end{array}$ & $\begin{array}{l}0.214^{*} \\
(0.204)^{*}\end{array}$ & $\begin{array}{c}0.006 \\
(0.014)\end{array}$ & $\begin{array}{c}0.054 \\
(0.051)\end{array}$ & $\begin{array}{c}0.218^{*} \\
(0.208)^{*}\end{array}$ & $\begin{array}{c}0.165 \\
(0.126)\end{array}$ & $\begin{array}{c}0.034 \\
(0.039)\end{array}$ & $\begin{array}{l}-0.007 \\
(-0.089)\end{array}$ & $\begin{array}{c}-0.154 \\
(-0.142)\end{array}$ & $\begin{array}{c}-0.071 \\
(-0.069)\end{array}$ & $\begin{array}{c}0.020 \\
(0.017)\end{array}$ & $\begin{array}{c}-0.046 \\
(-0.045)\end{array}$ \\
\hline DM & & $\begin{array}{r}0.350^{* *} \\
(0.314)^{* *}\end{array}$ & $\begin{array}{c}0.021 \\
(0.022)\end{array}$ & $\begin{array}{l}0.312 * * \\
(0.243)^{* *}\end{array}$ & $\begin{array}{c}0.361^{* *} \\
(0.307)^{* *}\end{array}$ & $\begin{array}{c}0.371^{* *} \\
(0.339)^{* *}\end{array}$ & $\begin{array}{c}0.115 \\
(0.098)\end{array}$ & $\begin{array}{c}0.009 \\
(0.016)\end{array}$ & $\begin{array}{c}0.370^{* *} \\
(0.334)^{* *}\end{array}$ & $\begin{array}{l}0.259 * * \\
(0.210) *\end{array}$ & $\begin{array}{c}-0.205^{*} \\
(-0.285)^{* *}\end{array}$ & $\begin{array}{l}-0.129 \\
(-0.113)\end{array}$ & $\begin{array}{c}-0.067 \\
(-0.060)\end{array}$ & $\begin{array}{c}-0.096 \\
(-0.089)\end{array}$ & $\begin{array}{c}0.020 \\
(0.015)\end{array}$ & $\begin{array}{c}0.245^{*} \\
(0.225)^{*}\end{array}$ \\
\hline PW & & & $\begin{array}{c}0.139 \\
(0.138)\end{array}$ & $\begin{array}{l}0.576 \text { ** } \\
(0.534)^{* *}\end{array}$ & $\begin{array}{c}0.547^{* *} \\
(0.531)^{* *}\end{array}$ & $\begin{array}{c}0.958^{* *} \\
(0.941)^{* *}\end{array}$ & $\begin{array}{c}0.023 \\
(0.023)\end{array}$ & $\begin{array}{c}0.042 \\
(0.044)\end{array}$ & $\begin{array}{c}0.941^{* *} \\
(0.921)^{* *}\end{array}$ & $\begin{array}{c}0.287^{* *} \\
(0.189)\end{array}$ & $\begin{array}{l}-0.029 \\
(-0.135)\end{array}$ & $\begin{array}{l}-0.024 \\
(-0.016)\end{array}$ & $\begin{array}{c}0.063 \\
(0.052)\end{array}$ & $\begin{array}{c}0.052 \\
(0.050)\end{array}$ & $\begin{array}{l}-0.043 \\
(-0.040)\end{array}$ & $\begin{array}{c}0.231^{*} \\
(0.223)^{*}\end{array}$ \\
\hline PH & & & & $\begin{array}{c}0.063 \\
(0.060)\end{array}$ & $\begin{array}{l}-0.001 \\
(0.010)\end{array}$ & $\begin{array}{c}0.089 \\
(0.092)\end{array}$ & $\begin{array}{c}0.007 \\
(0.001)\end{array}$ & $\begin{array}{c}0.057 \\
(0.050)\end{array}$ & $\begin{array}{c}0.082 \\
(0.087)\end{array}$ & $\begin{array}{c}-0.122 \\
(-0.088)\end{array}$ & $\begin{array}{c}0.067 \\
(0.064)\end{array}$ & $\begin{array}{l}-0.166 \\
(-0.156)\end{array}$ & $\begin{array}{c}0.125 \\
(0.110)\end{array}$ & $\begin{array}{c}-0.033 \\
(-0.029)\end{array}$ & $\begin{array}{c}0.042 \\
(0.040)\end{array}$ & $\begin{array}{c}0.001 \\
(0.001)\end{array}$ \\
\hline TL & & & & & $\begin{array}{c}0.659^{* *} \\
(0.604)^{* *}\end{array}$ & $\begin{array}{c}0.577^{* *} \\
(0.523)^{* *}\end{array}$ & $\begin{array}{c}-0.092 \\
(-0.071)\end{array}$ & $\begin{array}{c}0.047 \\
(0.039)\end{array}$ & $\begin{array}{c}0.557^{* *} \\
(0.504)^{* *}\end{array}$ & $\begin{array}{l}0.200^{*} \\
(0.123)\end{array}$ & $\begin{array}{l}-0.008 \\
(-0.013)\end{array}$ & $\begin{array}{c}0.019 \\
(0.022)\end{array}$ & $\begin{array}{l}-0.010 \\
(-0.013)\end{array}$ & $\begin{array}{c}0.038 \\
(0.034)\end{array}$ & $\begin{array}{l}-0.058 \\
(-0.047)\end{array}$ & $\begin{array}{c}0.219^{*} \\
(0.195)^{*}\end{array}$ \\
\hline SB & & & & & & $\begin{array}{c}0.522^{* *} \\
(0.501)^{* *}\end{array}$ & $\begin{array}{c}-0.108 \\
(-0.093)\end{array}$ & $\begin{array}{l}-0.013 \\
(-0.014)\end{array}$ & $\begin{array}{c}0.510^{* *} \\
(0.487)^{* *}\end{array}$ & $\begin{array}{c}0.144 \\
(0.088)\end{array}$ & $\begin{array}{c}-0.103 \\
(-0.105)\end{array}$ & $\begin{array}{c}0.111 \\
(0.099)\end{array}$ & $\begin{array}{c}0.043 \\
(0.028)\end{array}$ & $\begin{array}{c}-0.076 \\
(-0.071)\end{array}$ & $\begin{array}{c}0.053 \\
(0.053)\end{array}$ & $\begin{array}{c}0.232^{*} \\
(0.217)^{*}\end{array}$ \\
\hline $\mathrm{CP}$ & & & & & & & $\begin{array}{c}0.047 \\
(0.043)\end{array}$ & $\begin{array}{c}0.017 \\
(0.018)\end{array}$ & $\begin{array}{c}0.984^{* *} \\
(0.978)^{* *}\end{array}$ & $\begin{array}{c}0.516^{* *} \\
(0.458)^{* *}\end{array}$ & $\begin{array}{l}-0.047 \\
(-0.130)\end{array}$ & $\begin{array}{c}-0.049 \\
(-0.044)\end{array}$ & $\begin{array}{c}0.048 \\
(0.035)\end{array}$ & $\begin{array}{c}0.040 \\
(0.039)\end{array}$ & $\begin{array}{c}-0.099 \\
(-0.097)\end{array}$ & $\begin{array}{c}0.221^{*} \\
(0.215)^{*}\end{array}$ \\
\hline $\mathrm{SC}$ & & & & & & & & $\begin{array}{c}-0.027 \\
(-0.026)\end{array}$ & $\begin{array}{c}0.048 \\
(0.045)\end{array}$ & $\begin{array}{c}0.104 \\
(0.085)\end{array}$ & $\begin{array}{c}0.100 \\
(0.049)\end{array}$ & $\begin{array}{l}-0.107 \\
(-0.109)\end{array}$ & $\begin{array}{c}-0.091 \\
(-0.076)\end{array}$ & $\begin{array}{c}-0.096 \\
(-0.084)\end{array}$ & $\begin{array}{c}-0.001 \\
(-0.000)\end{array}$ & $\begin{array}{c}0.054 \\
(0.045)\end{array}$ \\
\hline TW & & & & & & & & & $\begin{array}{c}0.021 \\
(0.023)\end{array}$ & $\begin{array}{c}-0.084 \\
-(0.059)\end{array}$ & $\begin{array}{c}0.617^{* *} \\
\left(0.564^{* *}\right)\end{array}$ & $\begin{array}{c}0.049 \\
(0.044)\end{array}$ & $\begin{array}{c}0.066 \\
(0.065)\end{array}$ & $\begin{array}{c}0.049 \\
(0.046)\end{array}$ & $\begin{array}{c}0.070 \\
(0.078)\end{array}$ & $\begin{array}{c}-0.116 \\
(-0.107)\end{array}$ \\
\hline SY & & & & & & & & & & $\begin{array}{c}0.576^{* *} \\
(0.531)^{* *}\end{array}$ & $\begin{array}{c}-0.045 \\
(-0.136)\end{array}$ & $\begin{array}{c}-0.013 \\
(-0.010)\end{array}$ & $\begin{array}{c}0.081 \\
(0.066)\end{array}$ & $\begin{array}{c}0.078 \\
(0.077)\end{array}$ & $\begin{array}{c}-0.092 \\
(-0.091)\end{array}$ & $\begin{array}{c}0.230^{*} \\
\left(0.224^{*}\right)\end{array}$ \\
\hline HI & & & & & & & & & & & $\begin{array}{c}-0.090 \\
(-0.053)\end{array}$ & $\begin{array}{c}-0.013 \\
(-0.019)\end{array}$ & $\begin{array}{c}0.043 \\
(0.027)\end{array}$ & $\begin{array}{c}0.071 \\
(0.060)\end{array}$ & $\begin{array}{c}-0.192 \\
(-0.169)\end{array}$ & $\begin{array}{c}0.110 \\
(0.093)\end{array}$ \\
\hline $\mathrm{OP}$ & & & & & & & & & & & & $\begin{array}{c}0.167 \\
(0.174)\end{array}$ & $\begin{array}{c}0.038 \\
(0.015)\end{array}$ & $\begin{array}{c}0.197^{*} \\
(0.209)^{*}\end{array}$ & $=\begin{array}{l}-0.000 \\
(-0.001)\end{array}$ & $\begin{array}{c}-0.147 \\
(-0.145)\end{array}$ \\
\hline PA & & & & & & & & & & & & & $\begin{array}{c}0.056 \\
(0.056)\end{array}$ & $\begin{array}{c}0.391^{* *} \\
(0.381)^{* *}\end{array}$ & $\begin{array}{l}-0.056 \\
*(0.054)\end{array}$ & $\begin{array}{c}0.115 \\
(0.113)\end{array}$ \\
\hline SA & & & & & & & & & & & & & & $\begin{array}{c}0.146 \\
(0.148)\end{array}$ & $\begin{array}{c}-0.096 \\
(-0.086)\end{array}$ & $\begin{array}{c}0.041 \\
(0.043)\end{array}$ \\
\hline $\mathrm{OA}$ & & & & & & & & & & & & & & & $\begin{array}{c}-0.080 \\
(-0.077)\end{array}$ & $\begin{array}{c}-0.090 \\
(-0.089)\end{array}$ \\
\hline LA & & & & & & & & & & & & & & & & $\begin{array}{c}-0.194^{*} \\
\left(-0.190^{*}\right)\end{array}$ \\
\hline
\end{tabular}

${ }^{(1)} \mathrm{DF}$, days to flowering; DM, days to maturity; PW, plant weight (g); PH, plant height (cm); TL, tillers per plant; SB, secondary branches per plant; CP, capsules per plant; SC, seeds per capsule; TW, test weight (g); SY, seed yield (g); HI, harvest index (\%); OP, oil percentage (\%); PA, palmitic acid (\%); SA, stearic acid (\%); OA, oleic acid (\%); LA, linoleic acid (\%); and LNA, linolenic acid (\%). * and **Significant at 5 and $1 \%$ probability, respectively. 
Tadesse et al. (2010), Rahimi et al. (2011), and Pali \& Mehta (2014). The positive correlation of linolenic acid with days to maturity, plant weight, tillers per plant, secondary branches per plant, capsules per plant, and seed yield indicated that selection based on these traits would be useful in the development of varieties rich in linolenic acid.

Among all fatty acids, palmitic acid showed a significant positive association with oleic acid, while linoleic acid showed a significant negative association with linolenic acid and a negative association with oleic acid. Oleic acid, in turn, had a significant positive association with oil content. However, Bayrak et al. (2010) observed a positive association between palmitic acid and oil content. The negative correlations of linolenic acid with linoleic acid and of oleic acid with linoleic and linolenic acid can be best understood by the fatty acid biosynthesis pathway. You et al. (2014) found that both linoleic and linolenic acids have a common biosynthesis pathway, so one can increase at the cost of the other. Similar findings were also reported by Bayrak et al. (2010) and Pali \& Mehta (2014). The results obtained in the present study indicate that high oil content will result in high oleic acid, tending to increase linolenic acid and reduce oleic and linoleic acids. This shows that the increase in the oil content of the accessions will definitely enhance the oleic and palmitic acids. However, Pali \& Mehta (2014) suggested that an increase in oil will lead to an increase in linolenic acid. Bhatty (1995) and Bayrak et al. (2010) also observed a negative association of linoleic, oleic, and stearic acids with linolenic acid. Considering the obtained results, the present study suggests that selection to increase oil content would not affect linseed oil quality, since selection does not affect total fatty acid compositions, despite the noticeable changes in different fatty acids.

Simple correlations are less likely to provide a clear picture of the importance of each component trait in determining yield (Bhargava et al., 2007). In such condition, it becomes necessary to study the path coefficient analysis, which takes into account not only the causal relationship among traits, but also the degree of this relationship. Path analysis, also known as standardized partial regression coefficient, partitions the correlation coefficients into direct and indirect effects and, thereafter, allows the separation of the direct effects of each trait on yield from the indirect effects caused by the mutual association among the traits themselves (García del Moral et al., 2003). It should be pointed out that the traits days to flowering, plant weight, tillers per plant, capsules per plant, harvest index, and linolenic acid had a direct and indirect major role on seed yield (Table 4). Interestingly, these

Table 4. Estimates of direct (diagonal values in bold) and indirect (off-diagonal values) effects on seed yield per plant, at the genotypic level, of 17 morphological, agronomical, and chemical traits of 151 accessions of linseed (Linum usitatissimum) evaluated in 2012-2013 and 2013-2014(1).

\begin{tabular}{|c|c|c|c|c|c|c|c|c|c|c|c|c|c|c|c|c|c|}
\hline & $\mathrm{DF}$ & DM & PW & $\mathrm{PH}$ & TL & SB & $\mathrm{CP}$ & $\mathrm{SC}$ & TW & $\mathrm{HI}$ & $\mathrm{OP}$ & PA & SA & OA & LA & LNA & SY \\
\hline DF & 0.009 & -0.008 & 137 & 0.000 & 0.001 & 0.001 & 0.032 & .000 & & 0.049 & & & & & 0.000 & & 0.218 \\
\hline $\mathrm{M}$ & 0.004 & .018 & 48 & 000 & 0 & .001 & & 00 & & 077 & & & & & 000 & & .370 \\
\hline N & 0.001 & 5 & 0.7 & 0.001 & 0.003 & 002 & & 00 & & 086 & & & & & & & 0.941 \\
\hline $\mathrm{H}$ & 0.001 & -0.000 & 0.098 & 0.004 & 0.000 & 0.000 & & 000 & 0.000 & -0.036 & & & & & & & 0.082 \\
\hline $\mathrm{L}$ & 0.001 & -0.005 & 0.408 & 0.000 & 0.005 & -0.001 & & 000 & & 0.059 & & & -0.000 & 0.000 & -0.001 & 0.001 & 0.557 \\
\hline B & 0.001 & -0.006 & 0.388 & 0.000 & 0.003 & -0.002 & 0.0 & 000 & -0.0 & 0.043 & & 0.0 & 0.001 & -0. & & & 0.510 \\
\hline$P$ & 0.001 & -0.006 & 0.679 & 0.000 & 0.003 & -0.001 & 0.151 & 0.000 & 0.000 & 0.154 & 00 & -0.001 & 0.001 & 0.000 & -0.001 & 0.001 & 0.984 \\
\hline $\mathrm{C}$ & 0.000 & -0.002 & 0.016 & 0.000 & -0.000 & 0.000 & 0.007 & .000 & -0.000 & 0.031 & -0.001 & -0.001 & -0.001 & -0.001 & & & 0.048 \\
\hline W & 001 & 000 & & & 0.00 & 0.000 & & & & -0.025 & & & & & 001 & & 0.021 \\
\hline II & 0.001 & -0.004 & 0.203 & -0.000 & 0.001 & -0.000 & 0.078 & 0.000 & -0.001 & 0.298 & 0.000 & -0.000 & 0.000 & 0.000 & -0.002 & & 0.576 \\
\hline $\mathrm{P}$ & 0.000 & 0.003 & 20 & 0.000 & 0.000 & 0.000 & & 000 & & -0.027 & & 0.001 & & 0.0 & 0.000 & & -0.045 \\
\hline A & -0.000 & 0.002 & -0.017 & -0.001 & 0.000 & -0.000 & -0.007 & 0.000 & 0.001 & -0.004 & -0.001 & 0.010 & 0.001 & 0.003 & -0.001 & & -0.013 \\
\hline A & -0.001 & 0.001 & 0.045 & 0.001 & -0.000 & -0.000 & 0.007 & 0.000 & 0.001 & 0.012 & -0.000 & 0.0 & & 0.0 & -0.001 & & 0.081 \\
\hline A & -0.001 & 0.001 & 0.037 & -0.000 & 0.000 & 0.000 & 0.006 & 0.000 & 0.001 & 0.021 & -0.001 & 0.004 & 0.002 & 0.009 & 0.009 & -0.001 & 0.078 \\
\hline LA & 0.000 & -0.000 & -0.031 & 0.000 & -0.000 & -0.000 & -0.015 & 0.000 & 0.001 & -0.057 & 0.000 & -0.001 & -0.001 & -0.001 & & -0.001 & -0.092 \\
\hline LNA & -0.000 & -0.004 & 0.163 & 0.000 & 0.001 & -0.001 & 0.033 & 0.000 & -0.001 & 0.033 & 0.001 & 0.001 & 0.001 & -0.001 & -0.002 & 0.006 & 0.230 \\
\hline
\end{tabular}

${ }^{(1)} \mathrm{DF}$, days to flowering; DM, days to maturity; PW, plant weight (g); PH, plant height (cm); TL, tillers per plant; SB, secondary branches per plant; CP, capsules per plant; SC, seeds per capsule; TW, test weight (g); HI, harvest index (\%); OP, oil percentage (\%); PA, palmitic acid (\%); SA, stearic acid (\%); OA, oleic acid (\%); LA, linoleic acid (\%); LNA, linolenic acid (\%); and SY, seed yield (g). Residual effect $=0.1053$. 
traits also had a strong positive correlation with seed yield that evidenced the existence of a cause and effect relationship. Therefore, these traits can be considered reliable for selection for improved seed yield. The residual effect found was of 0.1053 , indicating that $90 \%$ of variation in yield components was determined by the characters evaluated in the present study.

\section{Conclusions}

1. The Gaurav, Shweta, and EX-3-3 accessions, for high seed yield, and Shubhra, Laxmi-27, and Shweta, for oil content, can be exploited for commercial cultivation, and simultaneous genetic improvement in these accessions can be based on simple selection.

2. The traits days to flowering, plant weight, tillers per plant, capsules per plant, harvest index, and linolenic acid exerted a major direct and indirect role on seed yield and also had a strong positive correlation with seed yield, indicating that they can also be considered as reliable traits for selection for improved seed yield.

3. The chemical profiling of fatty acids obtained in the present study can provide a platform for the selection of accessions for the genetic improvement of linseed.

\section{References}

ABOU EL-NASR, T.H.S.; HASSANIEN, M.S.; OTTAI, M.E.S.; AL-KORDY, M.A. Genetic diversity among five Romanian linseed varieties under Egyptian conditions. Middle East Journal of Applied Sciences, v.4, p.114-121, 2014.

AHMAD, R.; IBRAR, D.; MIRZA, Y.M.; MAHMOOD, T.; KHAN, M.A.; IQBAL, M.S.; AHMAD, M. Genetic variability, heritability and genetic advance in some genotypes of linseed Linum usitatissimum L. Journal of Agricultural Research, v.52, p.43-52, 2014.

BAYRAK, A.; KIRALAN, M.; IPEK, A.; ARSLAN, N.; COSGE, B.; KHAWAR, K.M. Fatty acid composition of linseed (Linum usitatissimum L.) genotypes of different origin cultivated in Turkey. Biotechnology and Biotechnology Equipment, v.24, p.1836-1842, 2010. DOI: 10.2478/V10133-010-0034-2.

BHARGAVA, A.; SHUKLA, S.; OHRI, D. Genetic variability and interrelationship among various morphological and quality traits in quinoa (Chenopodium quinoa Willd.). Field Crops Research, v.101, p.104-116, 2007. DOI: 10.1016/j.fcr.2006.10.001.

BHATTY, R.S. Nutrient composition of whole flax seed and flax seed meal. In: CUNNANE, S.C.; THOMPSON, L.U. (Ed.). Flaxseed in human nutrition. Champaign: AOCS Press, 1995. p. $22-42$.
BIBI, T.; MAHMOOD, T.; MIRZA, Y.; MAHMOOD, T.; EJAZUL-HASAN. Correlation studies of some yield related traits in linseed, Linum usitatissimum. Journal of Agricultural Research, v.51, p.121-132, 2013.

BLOEDON, L.T.; SZAPARY, P.O. Flaxseed and cardiovascular risk. Nutrition Reviews, v.62, p.18-27, 2004. DOI: 10.1111/j.17534887.2004.tb00002.x.

CHAUHAN, M.P.; SINGH, S.; SINGH, A.K. Post harvest uses of linseed. Journal of Human Ecology, v.28, p.217-219, 2009.

DEWEY, D.R.; LU, K.H. A correlation and path-coefficient analysis of components of crested wheatgrass seed production. Agronomy Journal, v.51, p.515-518, 1959. DOI: 10.2134/agronj19 59.00021962005100090002x.

DIEDERICHSEN, A.; FU, Y.-B. Flax genetic diversity as the raw material for future success. In: INTERNATIONAL CONFERENCE ON FLAX AND OTHER BAST PLANTS, 2008, Saskatoon. [Proceedings]... Saskatoon: Saskatchewan Flax Development Commission Institute of Natural Fibres; FAO/ Escorena European Cooperative Research Network on Flax and other Bast Plants, 2008. p.270-280.

EL-BELTAGI, H.S.; SALAMA, Z.A.; EL-HARIRI, D.M. Evaluation of fatty acids profile and the content of some secondary metabolites in seeds of different flax cultivars (Linum usitatissimum L.). General and Applied Plant Physiology, v.33, p.87-202, 2007.

GARCÍA DEL MORAL, L.F.; RHARRABTI, Y.; VILLEGAS, D.; ROYO, C. Evaluation of grain yield and its components in durum wheat under Mediterranean conditions. Agronomy Journal, v.95, p.266-274, 2003. DOI: 10.2134/agronj2003.0266.

JOHNSON, H.W.; ROBINSON, H.F.; COMSTOCK, R.E. Estimates of genetic and environmental variability in soybeans. Agronomy Journal, v.47, p.314-318, 1955a. DOI: 10.2134/agronj1 955.00021962004700070009x.

JOHNSON, H.W.; ROBINSON, H.F.; COMSTOCK, R.E. Genotypic and phenotypic correlations in soybeans and their implications in selection. Agronomy Journal, v.47, p.477-483, 1955b. DOI: 10.2134/agronj1955.00021962004700100008x.

KADRI BOZOKALFA, M.; ESIYOKHULYA ILBI, D.; KAYGISIZ ASCIOGUL, Z. Estimates of genetic variability and association studies in quantitative plant traits of Eruca spp. landraces. Genetika, v.42, p.501-512, 2010. DOI: 10.2298/ GENSR1003501B.

MILI, C.; BORA, G.C.; DAS, B.J.; PAUL, S.K. Studies on variability, heritability and genetic advance in Solanum melongena L. (Brinjal) genotypes. Direct Research Journal of Agricultural and Food Science, v.2, p.192-194, 2014.

MIRZA, M.Y.; KHAN, M.A.; AKMAL, K.M.; MOHMAND, A.S.; NAWAZ, M.S.; NAWAZ, N.; ULLAH, N. Estimation of genetic parameters to formulate selection strategy for increased yield in linseed. Pakistan Journal of Agricultural Research, v.24, p.19-24, 2011.

MOHAMMADI, A.A.; SAEIDI, G.; ARZANI, A. Genetic analysis of some agronomic traits in flax (Linum usitatissimum L.). Australian Journal of Crop Sciences, v.4, p.343-352, 2010. 
PALI, V.; MEHTA, N. Evaluation of oil content and fatty acid compositions of Flax (Linum usitatissimum L.) varieties of India. Journal of Agricultural Sciences, v.6, p.198-207, 2014. DOI: 10.5539/jas.v6n9p198.

PANSE, V.G. Genetics of quantitative characters in relation to plant breeding. Indian Journal of Genetics and Plant Breeding, v.17, p.318-328, 1957.

PANSE, V.G.; SHUKATME, P.V. Statistical methods for agricultural workers. $2^{\text {nd }}$ ed. New Delhi: Indian Council of Agricultural Research, 1967. 381p.

RAHIMI, M.M.; ZAREI, M.A.; ARMINIAN, A. Selection criteria of flax (Linum usitatissimum L.) for seed yield, yield components and biochemical compositions under various planting dates and nitrogen. African Journal of Agricultural Research, v.6, p.3167-3175, 2011. DOI: 10.5897/AJAR11.382.

REDDY, M.P.; REDDY, B.N.; ARSUL, B.T.; MAHESHWARI, J.J. Genetic variability, heritability and genetic advance of growth and yield components of linseed (Linum usitatissimum L.). International Journal of Current Microbiology and Applied Sciences, v.2, p.231-237, 2013.

SINGH, R.K.; CHAUDHARY, B.D. Biometrical methods in quantitative genetic analysis. New Delhi: Kalyani Publishers, 1985.

SINGH, S.P.; RAM, J.; WALIA, C.S.; SACHDEV, C.B.; DHANKAR, R.P.; RANA, K.P.C.; SEHGAL, J.; VELAYUTHAM, M.; GAJBHIYE, K.S. Soils of Uttar Pradesh for optimising land use. Nagpur: National Bureau of Soil Survey and Land Use Planning, 2004. 91p. (Soils of India series. NBSS publication, 68).

TADESSE, T.; PARVEN, A.; SINGH, H.; WEYESSA, B. Estimates of variability and heritability in linseed germplasm. International Journal of Sustainable Crop Production, v.5, p.8-16, 2010.

USMANI, G.; CHAWHAAN, P.H.; MISHRA, Y.; MANDAL, A.K. Variability, heritability and character association analysis of chemoagronomic traits in Rauwolfia serpentina. Euphytica, v.200, p.259-268, 2014. DOI: 10.1007/s10681-014-1153-x.

VARDHAN, K.M.V.; RAO, S.S. Genetic variability for seed yield and its components in linseed (Linum usitatissimum L.). International Journal of Applied Biology and Pharmaceutical Technology, v.3, p.200-202, 2012.

YADAVA, D.K.; VASUDEV, S.; SINGH, N.; MOHAPATRA, T.; PRABHU, K.V. Breeding major oil crops: present status and future research needs. In: GUPTA, S.K. (Ed.). Technological innovations in major world oil crops, volume 1: breeding. New York: Springer-Verlag, 2012. p.17-51. DOI: 10.1007/978-1-46140827-7.

YOU, F.M.; LI, P.; KUMAR, S.; RAGUPATHY, R.; LI, Z.; FU, Y.-B.; CLOUTIER, S. Genome-wide identification and characterization of the gene families controlling fatty acid biosynthesis in flax (Linum usitatissimum L). Journal of Proteomics and Bioinformatics, v.7, p.310-326, 2014. DOI: 10.4172/jpb.1000334.

Received on May 26, 2016 and accepted on July 21, 2016

Pesq. agropec. bras., Brasília, v.51, n.12, p.1964-1972, dez. 2016

DOI: 10.1590/S0100-204X2016001200007 